\title{
Kazimierz Twardowski jako mistrz i przełożony*
}

DOI: http://dx.doi.org/10.12775/RF.2014.009

W uniwersyteckich kręgach dziewiętnastowiecznej Europy uaktywniły się tendencje do usamodzielnienia psychologii. Warunkiem uzyskania przepustki do świata nauki było zbliżenie do niekwestionowanego wzorca - nauk przyrodniczych. Chodziło o wyraźne wyodrębnienie przedmiotu psychologii, o jego mierzalność i sprawdzalność empiryczna, o stosowanie naukowych metod badań oraz obiektywizację ich wyników przekształcanych w postać praw i teorii naukowych. Należało więc odrzucić metafizyczne spekulacje i zgłębiać naturę duszy (coraz częściej nazywanej psychiką, świadomością życiem psychicznym lub wewnętrznym) jako przedmiotu zainteresowań nowej nauki. Do realizacji tego planu należało zastosować obserwację i eksperyment - metody obiektywne i wypróbowane przez przyrodników. W dążeniach do osiągnięcia przez psychologię statusu autonomicznej nauki przodowali niemieccy psychofizycy i psychofizjologowie ${ }^{1}$.

Dokonując wyboru „przyrodniczej” drogi do naukowości psychologii, jej prekursorzy zarówno uzależniali się od metodologii stosowanej

Referat wygłoszony 7 listopada 2012 r. podczas konferencji nt. „Aktualność myśli psychologicznej Mieczysława Kreutza", Wydział Zamiejscowy SWPS, Wrocław.

1 T. Rzepa, Życie psychiczne i drogi do niego. Psychologiczna Szkoła Lwowska, Wydawnictwo Naukowe Uniwersytetu Szczecińskiego, Szczecin 1998; eadem, O interpretowaniu psychologicznym. W kręgu Szkoły Lwowsko-Warszawskiej, Polskie Towarzystwo Semiotyczne, Warszawa 2002; T. Rzepa, B. Dobroczyński, Historia polskiej myśli psychologicznej. Gałazki z drzewa Psyche, Wydawnictwo Naukowe PWN, Warszawa 2009; R. Stachowski, Historia wspótczesnej myśli psychologicznej. Od Wundta do czasów najnowszych, Wydawnictwo Scholar, Warszawa 2000; D. P. Schultz, S. E. Schultz, Historia współczesnej psychologii, Wyd. UJ, Kraków 2008. 
przez fizjologów, jak i oddalali od odwiecznych związków z filozofią. $\mathrm{Na}$ tym tle nie tylko nabrzmiewał spór dotyczący miejsca psychologii wśród innych nauk, lecz także aktywizowały się poważne konflikty osobiste. Wszak każdy, kto zapragnął uprawiać nową naukę, musiał nie tylko posiąść umiejętność stosowania introspekcji jako metody specyficznej dla psychologii, lecz przede wszystkim dokonać trudnego wyboru: pozostać przy tradycji jako psychologizujący filozof albo pójść śladem niemieckich nowatorów i stać się psychofizykiem lub psychofizjologiem. Mógł też poszukiwać "trzeciej” drogi. To zamieszanie wokół sposobu uprawiania modnej nauki sprawiło, że w ostatnich dziesięcioleciach XIX w. i na początku XX stulecia dominowały w Europie dwa nurty psychologii.

Pierwszy z nich, związany z działalnością naukową Gustawa Th. Fechnera (1801-1887) i Wilhelma Wundta (1832-1920), zwiastował nowe cele i obszary badawcze, przeznaczone dla psychologii. Powszechnie znanym efektem aktywności Wundta było powołanie psychologii eksperymentalnej i utworzenie pracowni psychologicznej wyposażonej w stale unowocześnianą aparaturę, pozwalającą na coraz dokładniejsze pomiary zmian fizjologicznych, zachodzących pod wpływem kontrolowanych bodźców fizycznych, rejestrowanych w świadomości jako wrażenia i uczucia.

Nurt drugi natomiast, pozostający w bliskich relacjach $\mathrm{z}$ filozofia, skoncentrowany był na poszukiwaniu drogi metodologicznej, powiązanej z rozważaniowym podejściem do naukowego poznania psychiki. Można go łączyć ze szkołami myślenia powstałymi na fundamencie krytyki psychologii eksperymentalnej, zwłaszcza z psychologią deskryptywną Franza Brentana (1838-1917), odcinającą się od paralelnego przyporządkowywania fenomenów świadomości zjawiskom fizjologicznym i fizycznym. Brentano dowodził, że przedmiotem psychologii są akty psychiczne (np. widzenie, słyszenie, smakowanie, wnioskowanie), nie zaś - jak głosił Wundt - ich treści. Warto dodać, że psychologia aktów była pierwowzorem holistycznego podejścia do procesów poznania, charakterystycznego nie tylko dla niebawem powołanej psychologii postaci, lecz i dla współczesnej psychologii humanistycznej.

Większość polskich uczonych, zainteresowanych psychologią i działających w opisanym okresie, zetknęła się z tymi nurtami psychologii. Powszechnym obyczajem było bowiem studiowanie $\mathrm{w}$ kilku zagranicznych ośrodkach uniwersyteckich i udział $\mathrm{w}$ zajęciach prowadzonych przez prekursorów psychologii naukowej, zwłaszcza przez Wundta. Do grona znaczących uczniów Brentana należy współtwórca polskiej nauki - Kazimierz Twardowski (1866-1938), który przeniósł i zaszczepił rozważaniowy styl uprawiania nauki swym studentom, w tym psychologom o lwowskim rodowodzie.

Twardowski pozostawał pod bezpośrednim wpływem Brentana przez dziewięć lat (1886-1894). Tak jak Brentano, nie zarzucił filozofii 
na rzecz uprawiania wyłącznie psychologii. Jak on, potrafił dokonać krytycznej oceny psychologii fizjologicznej oraz psychofizyki. I jak Brentano, wkroczył na drogę bliższą naukom humanistycznym aniżeli przyrodniczym, opartą na tradycji filozoficznej i nastawioną na poszukiwanie metod specyficznych dla psychologii. „Tak oto uniwersytet lwowski stał się punktem wyjścia określonego, nacechowanego duchem Franciszka Brentany [!] kierunku myślenia", zapisał Twardowski w swym dzienniku². Podobny wpis zamieścił w autobiografii:

czułem się powołany, by sposób filozofowania, jakiego nauczyłem się od Franciszka Brentany [!] zbliżyć moim rodakom, a w szczególności młodzież akademicką wprowadzić w ducha i metodę tej filozofii [...]. Samodzielność myślenia obok właściwej metody i czystego umiłowania prawdy zawsze uważałem za najpewniejsze rękojmie powodzenia w pracy naukowej3.

Realizacji tego celu sprzyjał jego legendarny autorytet, zachęcający do przejmowania wzorów analitycznego myślenia i interpretowania, samodyscypliny, osobistej odpowiedzialności, konsekwencji w działaniu, punktualności i zamiłowania do porządku' .

Właściwie od objęcia w 1895 r. katedry filozofii na Uniwersytecie Lwowskim, 29-letni Twardowski rozpoczął prace organizacyjne również "około" psychologii. Wygłaszał wykłady i prowadził seminaria z psychologii już od $1898 \mathrm{r}$. Był promotorem prac doktorskich i autorem tekstów propagujących nową dziedzinę nauki. Od 1901 r. kierował eksperymentami w prowizorycznej pracowni psychologicznej, a w $1907 \mathrm{r}$. uzyskał regularne dotacje na jej funkcjonowanie jako integralnej jednostki uniwersyteckiej. Twardowski zadbał także o staże i stypendia naukowe dla wyróżniających się uczniów, wspierając ich rozwój naukowy i umożliwiając im bezpośrednie korzystanie z dorobku nauki europejskiej. Dzięki niemu Władysław Witwicki (1878-1948), Stefan Baley (1885-1952), Stefan Błachowski (1889-1962) i Mieczysław Kreutz

2 K. Twardowski, Dzienniki, oprac. R. Jadczak, t. 1, Wyd. Adam Marszałek, Toruń 1997, s. 30.

3 Idem, Autobiografia filozoficzna, „Przegląd Filozoficzny. Nowa Seria” 1992, nr 1, s. 29.

4 K. Ajdukiewicz, Pozanaukowa działalność Kazimierza Twardowskiego, „Ruch Filozoficzny" 1959, nr 19 (1-2), s. 29-35; H. Słoniewska, Kazimierz Twardowski w psychologii polskiej, "Ruch Filozoficzny” 1959, nr 19 (1-2), s. 17-24; R. Jadczak, Kazimierz Twardowski. Twórca szkoły lwowsko-warszawskiej, Wyd. Adam Marszałek, Torun 1991; idem, Wstęp, w: K. Twardowski, Wybór pism psychologicznych i pedagogicznych, oprac. R. Jadczak, WSiP, Warszawa 1992; idem, Powstanie filozofii analitycznej w Polsce, Wyd. Adam Marszałek, Torun 1995; T. Rzepa, Psychologiczny portret Kazimierza Twardowskiego, w: R. Jadczak, Mistrz i jego uczniowie, Wydawnictwo Scholar, Warszawa 1997; eadem, Życie psychiczne i drogi do niego; eadem, O interpretowaniu psychologicznym. 
(1893-1971) nie tylko mogli się zapoznać z organizacją metodami i wynikami pracy ówczesnych luminarzy psychologii, lecz również uzyskać naukową samodzielność. To pozwoliło im na objęcie po 1918 r. katedr psychologii we wszystkich miastach uniwersyteckich, z wyjątkiem Krakowa, gdzie o kształcie psychologii decydował Władysław Heinrich (1869-1957), doktorant Richarda Avenariusa (1844-1896). Z wymienionych powodów Twardowskiego można uznać za twórcę zarówno filozoficznej, jak i psychologicznej szkoły naukowej. Szkołę filozoficzną z racji jej historycznej i merytorycznej ciągłości, gwarantowanej przez działalność uczniów Twardowskiego, zatrudnionych po 1918 r. na Uniwersytecie Warszawskim, zwykło się nazywać szkołą lwowsko-warszawską ${ }^{5}$. Szkołę psychologiczną natomiast, której geneza i rozwój wiążą się wyłącznie ze Lwowem, można określić mianem szkoły lwowskiej, przekazanej w 1928 r. Mieczysławowi Kreutzowi (1893-1971)6.

\section{Złożoność relacji Twardowski - Kreutz}

Po opuszczeniu Lwowa przez najstarszych uczniów - psychologów, Twardowski doprowadził w 1920 r. do utworzenia Zakładu Psychologii. Jednocześnie podjął dyplomatyczne i konsekwentne działania wokół przekształcenia go w samodzielną katedrę, choć w tym czasie nie miał odpowiedniego kandydata na jej kierownika. Rozglądając się za psychologiem $\mathrm{z}$ habilitacja, zdawał sobie w pełni sprawę z bezskuteczności poszukiwania kandydatów poza Lwowem, gdyż sam brał czynny udział w powojennych „wyścigach”, których celem było wychwytywanie samodzielnych pracowników nauki przez poszczególne - już polskie uczelnie, opuszczone przez kadrę rosyjska, pruską i austriacką. Dlatego podjął się pilotowania sprawy umieszczenia na tym stanowisku swego młodszego ucznia, Mieczysława Kreutza.

Decyzja Twardowskiego była podyktowana wyłącznie wyższymi racjami, wynikającymi z przypisywanej uniwersytetowi, rozumianemu jako „Świątynia nauki"7, wyjątkowej misji oraz z postawionego przed sobą zadania przyczynienia się do jej realizacji. Jak kilkakrotnie podkreślał

5 J. Woleński, Filozoficzna szkoła lwowsko-warszawska, PWN, Warszawa 1985; R. Jadczak, Kazimierz Twardowski. Twórca szkoły lwowsko-warszawskiej; idem, Wstęp; idem, Powstanie filozofii analitycznej w Polsce; idem, Mistrz i jego uczniowie; T. Rzepa, B. Dobroczyński, Historia polskiej myśli psychologicznej.

6 T. Rzepa, Kazimierz Twardowski jako organizator uniwersyteckich środowisk psychologicznych, „Przegląd Psychologiczny” 2000, nr 43 (1), s. 15-27; eadem, Myśl i praca Kazimierza Twardowskiego "około" polskiej psychologii, „Przegląd Psychologiczny” 2001, nr 44 (1), s. 133-149.

7 K. Twardowski, O dostojeństwie uniwersytetu, w: idem, Wybór pism psychologicznych i pedagogicznych. 
w dziennikach ${ }^{8}$, punktem honoru stało się dlań utworzenie samodzielnej katedry psychologii i prowadzenie studiów psychologicznych we Lwowie. Należy zaznaczyć, że decyzja ta nie wynikała z osobistych preferencji, kwalifikowanego wyboru czy sympatii, ponieważ stosunek Twardowskiego do Kreutza był dość skomplikowany ${ }^{9}$.

W dziennikach, prowadzonych przez Twardowskiego skrupulatnie od pierwszego dziesięciolecia XX w., Kreutz jest jedynie wzmiankowany, i to zazwyczaj negatywnie lub w klimacie oficjalnej obojętności. Zupełnie inaczej niż wielu wymienionych tam uczniów, których Twardowski chwalił za naukowe osiągnięcia, o imieninach których pamiętał, a nawet przytaczał relacje z długich dysput, które z nimi prowadził. Po raz pierwszy Kreutz pojawił się na kartach dziennika dopiero w 1925 r., gdy Twardowski pochwalił odczyt Jana Czekanowskiego (1882-1965) nt. eksperymentów pamięciowych i przy tej okazji sucho wzmiankował, że materiały wykorzystane $\mathrm{w}$ referacie zebrał Kreutz ${ }^{10}$. Tak odmienną niż wobec innych uczniów postawę Twardowskiego należy ocenić jako symptomatyczna, gdyż niemal zwyczajowo nawiązywał on z wybranymi uczniami dość bliskie i nie tylko naukowe relacje. Zapraszał ich bowiem do swego domu na słynne "herbatki”, częstował kolacjami, odwiedzał w chorobie, wspomagał $w$ trudnych sytuacjach życiowych. Przesiadywał z nimi długie godziny, najchętniej w kawiarni u „George'a” i w restauracji „Renaissance”, chadzał do teatru i na wieczorne spacery, spotykał się podczas wakacji spędzanych z reguły w Zakopanem. Twardowski nie odnotował obecności Kreutza w żadnym z tych miejsc. Ponadto, nie wymienił go jako uczestnika uroczystości uświęcających promocje doktorskie, które we lwowskich restauracjach organizowali koledzy i koleżanki Kreutza. Sporo wyjaśnia następująca charakterystyka: „Kreutz był taki porządny, skrupulatny, raczej bardzo drobiazgowy. I może dlatego nie miał on za bardzo dobrej prasy wśród swoich kolegów twardowszczaków. Oni raczej bardziej akceptowali styl swobodny, literacki, typowy dla Witwickiego czy Błachowskiego"11.

Jak wynika z bodaj najbardziej poufnej korespondencji Twardowskiego, którą prowadził z Władysławem Witwickim ${ }^{12}$, Kreutz kojarzył się Mistrzowi głównie z kłopotami oraz z koniecznością udzielania mu ciągłego

8 Idem, Dzienniki, oprac. R. Jadczak, t. 1 i 2, Wyd. Adam Marszałek, Torun 1997.

9 T. Rzepa, Kazimierz Twardowski jako organizator.

10 K. Twardowski, Dzienniki, t. 1, s. 205.

11 T. Tomaszewski, Twardowski, Witwicki, Kreutz i ja. Wypowiedźz z 30 stycznia 1988 r. (Warszawa), w: Dusza o podkładzie aktorskim. Władysław Witwicki, oprac. T. Rzepa, AMP Studio, Szczecin 2005, s. 74. Podobna, lecz ostrzejszą opinię o Mieczysławie Kreutzu wyraził kilkakrotnie w swej autobiografii Józef Pieter (Czasy i ludzie, Wyd. Adam Marszałek, Toruń 1997, s. 195, 267, 326-327), a nad wyraz ostrą - cytowany przezeń Bogdan Suchodolski (ibidem, s. 327).

12 T. Rzepa, O interpretowaniu psychologicznym. 
poparcia i podejmowania interwencji w jego sprawach, a przy tym - z okazywanym przeważnie niezadowoleniem zamiast oczekiwanych odruchów wdzięczności. Zdarzyło się tak na przykład wówczas, gdy Twardowski zaproponował mu poparcie w sprawie zarówno "zaszczytnego udziału” w pracach komisji egzaminacyjnej dla magistrów, jak i uzyskania statusu głównego egzaminatora z psychologii. Przedtem te ważne funkcje bardzo długo pełnił sam Twardowski, a ponieważ cenił je wysoko, więc postanowił przekazać planowanemu następcy. Najpierw Kreutz się zgodził, lecz po pewnym czasie złożył rezygnację, o czym nie raczył poinformować swego poprzednika na tych stanowiskach. To wydarzenie Twardowski opisał następująco:

U mnie Ajdukiewicz. Pokazuje pismo Kreutza wnoszące rezygnację z członkostwa w Państwowej Komisji egzaminacyjnej. Pismo wprost bezczelne. Pismo to, które zawiera bardzo ciężkie zarzuty [...] musi być oczywiście przedłożone Ministerstwu. Poradziłem Ajdukiewiczowi, aby zażądał od Kreutza uzasadnienia tych zarzutów i pismo Kreutza przedłożył Ministerstwu wraz z tym uzasadnieniem ${ }^{13}$.

Twardowskiego zniechęcały też pretensje zgłaszane przez Kreutza w kwestii naprawdę małych spraw i związana z tym skłonność do obrażania się. Przykładowo odnotował w dzienniku:

Z ciekawych epizodów tego posiedzenia warto podnieść sprawę Kreutza, zastępcy sekretarza, który oświadczył, że nie chce być nazywany w sprawozdaniu zastępcą sekretarki - sekretarzuje teraz bowiem od paru lat Dania $^{14}$. Wniosek, by go nazwać zastępcą sekretarza i w związku z tym Danię sekretarzem, został uchwalony, choć oświadczyłem się przeciw temu ${ }^{15}$.

Twardowskiego zniechęcała również postawa roszczeniowa wobec władz uniwersyteckich, którą przypisywał Kreutzowi. Otóż, zdaniem Twardowskiego, Kreutz wyjątkowo ociagał się z przygotowaniem rozprawy habilitacyjnej. $Z$ tego powodu przedłużały się zabiegi o utworzenie samodzielnej katedry psychologii. Z tego samego powodu Twardowski corocznie musiał nie tylko występować z wnioskami, lecz osobiście lub przez lwowskich posłów i senatorów interweniować $\mathrm{w}$ ministerstwie $\mathrm{w}$ sprawie tzw. zleconych wykładów i ćwiczeń z psychologii, które prowadził dr Kreutz. Dla Twardowskiego zabiegi te były upokarzające, gdyż dobrze wiedział, że: „Ponieważ nie ma katedry psychologii, więc takie wykłady

13 K. Twardowski, Dzienniki, t. 2, s. 369-370.

14 Daniela Gromska (1889-1973) - historyk filozofii i filolog klasyczny, w latach 1918-1923 asystentka Kazimierza Twardowskiego.

15 K. Twardowski, Dzienniki, t. 2, s. 54. 
nie są możliwe, ale Ministerstwo gotowe mu [Kreutzowi - T. R.] dać 2 godziny zleconych wykładów i pięć godzin ćwiczeń"16. I dalej rozważał: "Ciekaw jestem, czy Kreutz to przyjmie - swego czasu oświadczył, że tylko wtedy będzie dalej w Uniwersytecie pracował, gdy otrzyma zastępstwo wykładów (zastępstwo profesora, jak się to zwykle u nas zowie)". Chodziło o to, czy Kreutz zgodzi się prowadzić zajęcia na zasadzie dzisiejszych godzin zleconych, bez uzyskania etatu $z w$. zastępcy profesora. $Z$ powodu takich oświadczeń, jak przywołane, Twardowski musiał się liczyć z możliwością odmowy z jego strony, a tym samym nie tylko zabiegać w ministerstwie o dotację na zlecenie zajęć z psychologii, lecz także prosić Kreutza o to, by je przeprowadził. Przebieg jednej z rozmów na ten temat opisał Twardowski następująco:

Mówiłem mu [Kreutzowi] dalej o tym, że Ministerstwo zleciło mu wykłady i ćwiczenia w III trymestrze, prosiłem go, by oświadczył po namyśle, czy się ich podejmie, skoro nie zostały mu zlecone - jak się tego dawniej kategorycznie domagał - w formie zastępstwa katedry. Wspominał mi, że byłaby możliwość uzyskania posady w Bibliotece Ossolińskich i że on wolałby tę posadę od posady nauczyciela gimnazjalnego, że jednak trzeba by tu poparcia [...]. Może liczył na to, że mu tego poparcia użyczę, ale gdybym nawet nie miał po różnych doświadczeniach z nim poczynionych pewnych wątpliwości, czy mogę go polecić - wszak i to, o czym dzisiaj mi opowiadał dowodzi, jak mało on się liczy z tymi, co go popierają - nie mógłbym go protegować $[\ldots]^{17}$.

Mimo że po tej rozmowie, która odbyła się 27 lutego, 10 dni później Kreutz wyraził zgodę na prowadzenie zajęć z psychologii, to i tak swą decyzję postanowił zmienić $\mathrm{w}$ najgorszym momencie, bo pierwszego października:

Był u mnie po południu Kreutz radzić się, czy nie mógłby odroczyć rozpoczęcia wykładów swoich, skoro dotąd nie nadeszło jeszcze z Warszawy zlecenie jego wykładów. Powiedziałem mu, że nie mogę tu nic mu powiedzieć, gdyż to jest sprawa, z którą winien się zwrócić do Dziekana, co też postanowił uczynić. Ale nie podobało mi się to - zawsze z nim są jakieś trudności i nic gładko nie idzie ${ }^{18}$.

Następnego dnia zlecenie nadeszło, o czym Twardowski poinformował Kreutza 3 października, na co ten tym razem „wyraził zamiar wzięcia bezpłatnego urlopu od zajęć gimnazjalnych i pytał się, jak stoi

16 Ibidem, t. 1, s. 224.

17 Ibidem, s. 231.

18 Ibidem, s. 267. 
sprawa katedry. Powiedziałem, że nic pewnego nie wiem - bo nic przewidzieć się nie da"19.

Jednak tę corocznie przerabianą i negatywnie przez Twardowskiego ocenianą sprawę wkrótce przyćmiło wydarzenie, które jeszcze bardziej skomplikowało jego stosunek do Kreutza ${ }^{20}$. Otóż, na przełomie lat 1925-1926, dzięki poparciu Twardowskiego, Kreutz otrzymał stypendium rządowe z przeznaczeniem na studia zagraniczne. Jednak wkrótce okazało się, że część tej sumy rozdysponował według własnego uznania. Mimo że cel, na który przeznaczył rządowe pieniądze, należy ocenić jako szlachetny, to ukrywanie tej decyzji przed rekomendującym go przełożonym zostało ocenione jako niewłaściwe. Tym bardziej że Twardowski otwarcie i wielokrotnie głosił, że za wyjątkowo „skandaliczną" uznaje "postawę przedkładania prywaty nad dobro publiczne" ${ }^{21}$. To wydarzenie zostało dokładnie opisane $\mathrm{w}$ dzienniku ${ }^{22}$ :

Idąc $\mathrm{w}$ południe $\mathrm{z}$ nowego gmachu na wykład logiki dla medyków, spotkałem się ze zdążającym do mnie Kreutzem! Wrócił już ze swych podróży zagranicznych, choć otrzymał niedawno trzecią ratę stypendialną na pobyt zagraniczny do końca marca! Opowiedział mi, że z powodu bardzo ciężkiej choroby jego siostry, cierpiącej na gruźlicę i bawiącej z matką w Zakopanem, był zmuszony przyjść jej z pomocą finansową i dlatego skrócił swój pobyt za granicą o miesiąc, a oszczędzone w ten sposób pieniądze posłał swej siostrze, i że zamierza prosić Ministerstwo, by pozwoliło mu zwrócić tę kwotę ewentualnie w ratach. Przedstawiłem mu niewłaściwość jego postępowania, zwracając mu uwagę, że on samowolnie zmienił przeznaczenie udzielonych mu przez Ministerstwo pieniędzy, przemieniając stypendium zagraniczne na osobistą pożyczkę. Nalegałem, by jak najprędzej uporządkował tę sprawę, gdyż i ja jestem w niej angażowany jako ten, który się o stypendium dla niego starał.

Próba zdiagnozowania relacji Twardowski - Kreutz na podstawie opisanych wydarzeń prowadzi do stwierdzenia, że Twardowski pozostawał przez lata w pułapce psychologicznej. Tę uzależniającą go od Kreutza pułapkę przygotował sobie sam od momentu, gdy podjął zabiegi wokół ulokowania innych uczniów - psychologów poza Lwowem. Kiedy bowiem wyekspediował ich do Warszawy, Poznania i Wilna, musiał postawić na Kreutza i liczyć na jego rychły rozwój naukowy. W tych nadziejach i kalkulacjach kierował się głównie - deklarowanym jako wy-

19 Ibidem, s. 268.

20 R. Jadczak, Mistrz i jego uczniowie; T. Rzepa, Kazimierz Twardowski jako organizator.

21 K. Twardowski, Przemówienie wygłoszone na obchodzie dwudziestopięciolecia Polskiego Towarzystwa Filozoficznego we Lwowie dnia 12 lutego 1929, w: idem, Wybrane pisma filozoficzne, PWN, Warszawa 1965.

22 Idem, Dzienniki, t. 1, s. 231. 
łączny - celem utworzenia katedry psychologii w UJK, choć nie można tu pomijać motywów stricte naukowych. Tych Twardowski oczywiście nie pomijał; raczej ich nie pochwalał, prawdopodobnie dlatego, że nie akceptował sposobu uprawiania psychologii przez Kreutza, który - jak na owe czasy - starał się to czynić nowatorsko, poszukując "trzeciej” drogi dla młodej dyscypliny naukowej.

Posługiwał się Kreutz pierwszymi metodami statystycznymi, które były - co prawda - jeszcze proste, ale pozwalały nowocześnie zajmować się psychologią. [...] Kreutz - to była rewolucja psychologiczna na skalę lwowską. On wziął od Twardowskiego najważniejsze - nastawienie na ścisłość i precyzję. Oczywiście, trzeba od razu sprawiedliwie powiedzieć, że Twardowski to był umysł o wiele większy od Kreutza ${ }^{23}$.

Jak można przypuszczać, z każdym miesiącem po podjęciu decyzji o wykreowaniu Kreutza na swego następcę, Twardowski utwierdzał się w przekonaniu o jej nietrafności. Między nimi nieustannie występowały nieporozumienia i tarcia, ujawniały się kolejne różnice, a wzajemne stosunki cechowała skrywana niechęć, chłód i narastający dystans. W rezultacie i "Kreutz był właściwie antagonistą Twardowskiego" ${ }^{24}$. Jednakże zarówno typowa dla Twardowskiego konsekwencja działania, jak i uporczywa świadomość, że wskutek własnej decyzji spośród uczniów - psychologów ostał się we Lwowie tylko Kreutz, spowodowały, że ciągle liczył na jego usamodzielnienie się oraz oczekiwał na organizacyjne i naukowe sukcesy. Nie ma przy tym podstaw, aby sądzić, że potrafił go odpowiednio zmotywować - podobnie jak nie ma podstaw, aby sądzić, że obaj nie zdawali sobie sprawy z ciągnącej się latami sytuacji konfliktowej.

Twardowski umiał ocenić charakter ich wzajemnych relacji jako uzależniający i jedynie $\mathrm{w}$ tajemnicy, w korespondencji z Witwickim jako najbardziej zaufanym i najstarszym uczniem, wyrażał swe wątpliwości co do Kreutza i dopytywał o możliwość pozyskania innego kandydata na lwowską katedrę psychologii. Z listów i dzienników wiadomo, że z Kreutzem spotykał się niemal wyłącznie na uniwersytecie i że podczas tych spotkań zachowywał odpowiednie pozory, możliwe dzięki uruchamianiu (właściwej sobie) stoickiej postawy życiowej. Wiadomo też, że podczas rozmów z Kreutzem wyjątkowo dbał o to, aby nie wypowiedzieć ani jednego słowa za dużo. Jednocześnie, jakby przekonując samego siebie, wielokrotnie formował reakcję przeciwną (tj. nadmiernej uprzejmości i wyrozumiałości), co jeszcze bardziej zafałszowywało ich wzajemne relacje. Stąd też - mimo negatywnej postawy wobec Kreutza -

23 T. Tomaszewski, Twardowski, Witwicki, Kreutz i ja, s. 73-74.

24 Ibidem, s. 75. 
właściwie każdorazowo udzielał mu żądanego poparcia, interweniował w jego sprawach, przekonywał swych uniwersyteckich kolegów o jego przydatności dydaktycznej i talentach naukowych, bronił przed krytyka a nawet co najmniej dwukrotnie uczynił dla niego coś więcej niż dla innych uczniów. Na przykład, co dla Twardowskiego niebywałe ${ }^{25}$, bo tego przywileju nie otrzymał nikt inny, wręczył mu zapasowy klucz do zakładowej biblioteki, dzięki czemu Kreutz mógł tam wchodzić i korzystać z jej zasobów bez koniecznej zgody Mistrza.

\section{Kulisy batalii o katedrę psychologii i habilitację Kreutza}

W tak bardzo psychologicznie zagmatwany sposób plany, nadzieje i rozczarowania Twardowskiego splatały się z milczeniem, roszczeniami i pretensjami Kreutza przez kilka długich lat. Dopiero w 1926 r., dokładnie 31 sierpnia, we wtorkowe południe

był u mnie Kreutz, pokazał mi rękopis swej pracy habilitacyjnej o zmienności rezultatów testów. Oświadczył gotowość złożenia 30 złotych na rzecz PTF w celu ułatwienia wydania tej pracy nakładem Towarzystwa. Oświadczyłem mu, że Towarzystwo przyjęłoby tę pomoc tylko w postaci pożyczki ${ }^{26}$.

W tym momencie odżyły dawne projekty i sześćdziesięcioletni, już schorowany, lecz znów entuzjastycznie nastawiony, Twardowski podjął odpowiednie kroki organizacyjne. Jak konsekwentnie podkreślał, nie kierowały nim pobudki osobiste, ponieważ Kreutz takich w nim nie wzbudzał, lecz wzgląd na dobro publiczne, skonkretyzowany jako plan powołania katedry psychologii. W grudniu 1926 r. Twardowski przedłożył komisji wydziałowej referat „w sprawie nadzwyczajnej Katedry psychologii i proponowania obsadzenia jej zastępczo przez Kreutza"27. Kilka dni później odbyło się „posiedzenie Rady Wydziałowej, na której [postanowiono] Kreutzowi powierzyć zastępstwo wykładów i ćwiczeń psychologicznych, przy równoczesnym wszczęciu starań o nadzwyczajną Katedrę psychologii. Ten ostatni wniosek przeszedł słabą bardzo większością, mianowicie na 19 głosujących za było $11^{\prime 28}$. Nie trzeba wyjaśniać, kto wchodził w skład pro-Kreutzowej jedenastki. Wkrótce, bo na początku lutego 1927 r., Twardowski przeforsował zgodę członków PTF na druk rozprawy Kreutza za pieniądze Towarzystwa.

25 T. Rzepa, Psychologiczny portret Kazimierza Twardowskiego.

26 K. Twardowski, Dzienniki, t. 1, s. 262.

27 Ibidem, s. 280.

28 Ibidem, s. 282. 
Niemal jednocześnie, bo pod koniec marca, nadeszła decyzja z ministerstwa, powołująca w roku akademickim 1927/1928 dwie katedry na Uniwersytecie Jana Kazimierza: filozofii i pedagogiki lub psychologii ${ }^{29}$. Wobec braku jednoznacznej decyzji ministerialnej, Twardowski odnotował, że ówczesny dziekan „żądał, bym w projekcie odpowiedzi oświadczył się za przeznaczeniem jej dla pedagogiki. Wyraziłem wątpliwość, czy tak będzie dobrze, wyraziłem też zdanie, że lepiej będzie naprzód żądać katedry nadzwyczajnej psychologii" ${ }^{\prime 30}$. Jednak dziekan był nieubłagany, więc niebawem Twardowski przygotował projekt pisma skierowanego do ministerstwa, z uzasadnieniem potrzeby powołania katedry pedagogiki. Pismo zostało zaakceptowane przez dziekana. W świetle posiadanych przez Twardowskiego informacji o braku kandydatów na obsadzenie takiej katedry oraz o mającej się lada moment ukazać książce Kreutza, było to znakomite posunięcie.

W czasie tych rozgrywek, dzięki interwencji Twardowskiego, została wydrukowana rozprawa habilitacyjna Kreutza ${ }^{31}$. Następnym krokiem było złożenie (19 maja) odpowiednich dokumentów. Po czym, już tydzień później, Twardowski osobiście stawił się w ministerstwie.

od pierwszej do drugiej miałem rozmowę [...] na Hożej 88. [...] Co do Kreutza, dla którego prosiłem o wykłady zastępcze, Michalski ${ }^{32}$ jest z rezerwą wielką. O zastępczych wykładach nie może być, zdaniem Michalskiego, mowy, dopóki nie ma we Lwowie katedry psychologii. I poza tym należy jego zdaniem czekać, aż Kreutz się wybije [...]. Lepiej nawet może na kilka lat zakontraktować cudzoziemca niż słabszą siłą własną katedrę na lata całe nieodpowiednio obsadzić! Widzę, że z Kreutzem będzie sprawa niełatwa ${ }^{33}$.

Pomimo kolejnych dowodów na rzecz ogólnie niechętnej postawy wobec Kreutza, Twardowski postanowił walczyć dalej. Jednak tuż po jego powrocie z Warszawy, w pierwszych dniach czerwca 1927 r. znów wokół Kreutza nastąpiło pewne zamieszanie. Został on bowiem powołany do odbycia kilkumiesięcznych ćwiczeń wojskowych. Mimo że dziekan natychmiast wystąpił o zwolnienie go z tych ćwiczeń i mimo że po trzech dniach zwolnienie uzyskał, ten już zdążył zawiesić uniwersyteckie zajęcia i wyjechać. Trzeba było kolejnych zachodów, by go na powrót ściaggać do

29 T. Rzepa, Kazimierz Twardowski jako organizator; eadem, Myśl i praca Kazimierza Twardowskiego.

30 K. Twardowski, Dzienniki, t. 1, s. 300.

31 M. Kreutz, Zmienność rezultatów testów, cz. 1: Znaczenie zmienności rezultatów dla wartości testów, Polskie Towarzystwo Filozoficzne, Lwów 1927.

32 Stanisław Michalski (1865-1949) - ówczesny dyrektor Funduszu Kultury Narodowej, kierownik oddziału naukowego Kasy im. Mianowskiego.

33 K. Twardowski, Dzienniki, t. 1, s. 309. 
Lwowa. Niebawem po tym wydarzeniu, zrażony zachowaniem Kreutza, dziekan oświadczył Twardowskiemu,

że będzie lepiej, jeśli się nie będzie już forsowało w tym trymestrze przeprowadzenia habilitacji Kreutza. Dał do zrozumienia, że i tak habilitacja Kreutza natrafi na opozycję, więc lepiej nie przebiczowywać jej pod koniec roku. Powiedziałem to Kreutzowi, ale nie wspominając o owej przewidywanej przez Dziekana opozycji ${ }^{34}$.

Na tę informację Kreutz zareagował jak zwykle, czyli szantażem. Oświadczył bowiem, że $\mathrm{w}$ takim układzie on nie poprowadzi wykładów z psychologii w przyszłym roku akademickim, lecz weźmie tylko ćwiczenia. $W$ imię uznawanych przez siebie wyższych wartości i motywów działania, Twardowski „przełknął i tę żabę”. Błyskawicznie podjął odpowiednie i sobie wiadome działania, po czym już 22 czerwca $1927 \mathrm{r}$. rada wydziału postanowiła dopuścić Kreutza do habilitacji.

Po dwugodzinnej dyskusji, 1 grudnia 1927 r. komisja habilitacyjna, powołana w sprawie Kreutza, ostatecznie przyjęła odpowiednio przygotowany referat Twardowskiego omawiający naukowe osiągnięcia habilitanta, choć znawca statystyki matematycznej - Jan Czekanowski - zgłosił wiele zastrzeżeń pod adresem przedłożonej rozprawy. Kolokwium habilitacyjne odbyło się w środę, 7 grudnia, a wykład wygłosił Kreutz 10 grudnia, otrzymując tego dnia veniam legendi z psychologii.

Uzyskanie przez Kreutza naukowej samodzielności równoznaczne było nie tylko z realizacją szczytnego celu wytyczonego sobie przed przeszło 10 laty przez Twardowskiego, lecz także ze zwycięstwem nad pedagogami w wyścigu o uniwersytecką katedrę. Nie bacząc więc na dotychczasowe opinie i preferencje dziekana oraz członków rady wydziału, Twardowski nareszcie mógł wystąpić z upragnionym wnioskiem. W celu przygotowania gruntu pod pomyślne i ostateczne załatwienie sprawy, w maju 1928 r. pojechał do Warszawy i - dzięki swym koneksjom - uzyskał ministerialne zapewnienie, że na realizację jego projektu „są pewne widoki"35. Natychmiast przygotował wniosek o powołanie katedry psychologii i mianowanie Kreutza zastępcą profesora oraz o powierzenie mu pieczy nad pracownią psychologiczną. Wniosek został pozytywnie przegłosowany przez radę wydziału pod koniec czerwca 1928 r. ${ }^{36}$, a już 4 lipca Twardowski zapisał: „Dowiedziałem się, że dzisiaj przyszło pismo z Ministerstwa, godzące się na przemianę katedry pedagogiki na katedrę

34 Ibidem, s. 313.

35 Ibidem, t. 2, s. 25.

36 R. Jadczak, Mistrz i jego uczniowie; T. Rzepa, Kazimierz Twardowski jako organizator. 
psychologii (nadzwyczajną) i na poruczenie Kreutzowi zastępstwa tej katedry" ${ }^{\prime 7}$.

Wieloletnie zabiegi Twardowskiego na rzecz utworzenia katedry psychologii we Lwowie uwieńczył szczęśliwy dzień - 3 października 1928 r. To wydarzenie zostało wyjątkowo podniośle utrwalone w dzienniku:

Po południu posiedzenie Rady Wydziałowej [...]. Wśród komunikatów dzisiejszego posiedzenia Dziekan odczytał pismo Senatu Akademickiego, który w odpowiedzi na wystosowane doń na mój wniosek w czerwcu przez Radę Wydziałową zapytanie, czy Rada Wydziałowa, powierzając zastępcy profesora kierownictwo zakładu naukowego, tym samym poruczyła mu też całą administrację zakładu, odpowiedział, że tak. Tym sposobem Dr Mieczysław Kreutz, który od 1. bm. jest na mój wniosek zastępcą profesora psychologii i kierownikiem Zakładu psychologicznego, obejmuje też całkowite kierownictwo Zakładu, ja zaś przestaję się zajmować Zakładem tym pod każdym względem. Kończy się tedy długi okres mojej pracy sięgającej od pierwszych prób stworzenia we Lwowie pracowni psychologicznej w roku 1901 [...] do w 1928 r. utworzenia samodzielnego Zakładu psychologicznego i uzyskania w roku 1928 obszernego dla niego Zakładu w nowym gmachu uniwersyteckim. Dr Kreutz szczęśliwszy ode mnie, otrzymuje w postaci gotowej to, co musiałem tworzyć w każdym szczególe krok za krokiem ${ }^{38}$.

\section{Wysiłki w sprawie profesury Kreutza}

Niech nikogo nie zmylą podniosłe słowa Twardowskiego. Należy je interpretować raczej jako taktowną pochwałę samego siebie oraz swych wieloletnich zabiegów wokół utworzenia katedry psychologii i przyczynienia się do rozwoju lwowskiej uczelni. Bo też Twardowski nie poprzestał na tym, co do tej pory uczynił. Jednakże, niemal przez dwa lata nie poświęcił Kreutzowi ani jednego zdania w swym dzienniku, co może dowodzić niezmienności jego negatywnej postawy wobec swego następcy. Milczenie trwało do dnia, kiedy Kreutz postanowił podjąć zabiegi w celu uzyskania nadzwyczajnej profesury. Zgłosił się 30 kwietnia 1930 r. do Twardowskiego, by ten poparł druk jego książki, stanowiącej kontynuację problematyki poruszonej w pracy habilitacyjnej. Książka miała być podstawą starań o stanowisko profesora.

Mimo że już w pierwszych dniach października 1930 r. Twardowski uzyskał pozytywną opinię członków PTF co do opublikowania tej pracy nakładem Towarzystwa, to Kreutz jeszcze jej nie ukończył. Zaczął ją do-

37 K. Twardowski, Dzienniki, t. 2, s. 32.

38 Ibidem, s. 44. 
starczać Twardowskiemu we fragmentach dopiero w 1932 r., gdyż wcześniej był zajęty przygotowaniem skryptu z podstaw psychologii oraz książki z zakresu psychologii rozwojowej ${ }^{39}$. Ostatecznie w lutym 1933 r., po lekturze całości drugiej części pracy na temat zmienności rezultatów testów, Twardowski omówił z nim konieczne poprawki i konferował „W sprawie wyboru drukarni dla II części pracy Kreutza. Uchwaliliśmy oddać druk Drukarni Związkowej"40.

To wówczas miał miejsce drugi czyn wspomniany tu i oceniony jako niebywały dla Twardowskiego ${ }^{41}$. Wykonał on, mianowicie, własnoręcznie pierwszą i drugą korektę nowej książki Kreutza, stanowiącej kontynuację rozprawy habilitacyjnej ${ }^{42}$. Zgodnie z dziennikowymi zapiskami, poświęcił na tę pracę dokładnie $21 \mathrm{dni}$, wykonując ją w okresie od 6 kwietnia do 16 czerwca 1933 r. Przy tej żmudnej pracy pomagała Twardowskiemu jego ulubiona uczennica, Izydora Dąmbska (1904-1983), która poświęciła na to sporo godzin, skrupulatnie przez Mistrza odnotowanych w dzienniku. O docenieniu tych wysiłków przez Kreutza świadczy to, że po raz pierwszy i ostatni w czasie trwania ich znajomości pojawił się 14 kwietnia w domu Twardowskiego i złożył mu życzenia wielkanocne.

Po opublikowaniu pracy w 1933 r., Mieczysław Kreutz wystąpił $\mathrm{z}$ wnioskiem o profesurę nadzwyczajną. Posiedzenie komisji $\mathrm{w}$ tej sprawie odbyło się 13 lutego 1934 r. Zdania co do obsadzenia Kreutza na katedrze znów były podzielone. Na wniosek Romana Ingardena (1893-1970) „uchwalono (ja wstrzymałem się od głosu) zwrócić się także do wszystkich profesorów filozofii o ich zdanie co do najodpowiedniejszego kandydata na Katedrę psychologii" ${ }^{43}$. Wkrótce okazało się, że odpowiedzi adresatów były nieliczne i jednoznacznie popierające stanowisko Twardowskiego, stąd też 16 marca „uchwalono przedstawić Radzie Wydziałowej wniosek zaproponowania Ministerstwu wyjednania nominacji Kreutzowi na nadzwyczajnego profesora psychologii" ${ }^{44}$. Przygotowanie referatu $\mathrm{w}$ tej sprawie i wygłoszenie go na radzie wydziału powierzono Ajdukiewiczowi (1890-1963), z którym Twardowski kilkakrotnie konferował na temat Kreutza, m.in. w niedzielę tuż przed środowym posiedzeniem rady: „Po południu miałem dłuższą rozmowę telefoniczną z Kazikiem w sprawie kandydatury Kreutza na profesora psychologii u nas. Wiele wątpliwości i trudności" ${ }^{\prime 5}$.

39 M. Kreutz, Rozwój psychiczny młodzieży, Książnica - Atlas, Lwów-Warszawa 1931.

40 K. Twardowski, Dzienniki, t. 2, s. 273.

41 T. Rzepa, Psychologiczny portret Kazimierza Twardowskiego.

${ }^{42}$ M. Kreutz, Zmienność rezultatów testów, cz. 2: Przyczyny zmienności rezultatów i konieczna modyfikacja metody testów, Polskie Towarzystwo Filozoficzne, Lwów 1933.

43 K. Twardowski, Dzienniki, t. 2, s. 328.

44 Ibidem, s. 332.

45 Ibidem, s. 338. 
W rezultacie z górą trzydziestoletnich wysiłków i starań Twardowskiego, również i ten jego uczeń uzyskał nadzwyczajną profesurę z filozofii i objął kierownictwo katedry psychologii na Uniwersytecie Jana Kazimierza. Pod datą 25 kwietnia 1934 r. Twardowski zapisał ważną informację, choć już bez specjalnego entuzjazmu: „jak mi telefonował [Kazimierz Ajdukiewicz] niedawno z Uniwersytetu, wniosek Komisji w sprawie propozycji Kreutza na nadzwyczajnego profesora filozofii przeszedł na Radzie Wydziałowej jednomyślnie"46. Ministerialną nominację na profesora nadzwyczajnego otrzymał Kreutz 18 grudnia 1934 r.

Cokolwiek sądzić na temat naukowej, dydaktycznej i organizacyjnej działalności Kreutza, niezaprzeczalnie nie było mu łatwo. Przecież poruszał się w cieniu wielkości Twardowskiego, pod jego czujnie krytycznym wzrokiem, uważnie obserwującym i surowo recenzującym jego poczynania. Prawdopodobnie nie umiał sobie z tym poradzić, bo przecież trudno konkurować z kimś tak legendarnym oraz trudno przełamać tworzoną przez niego tradycję i proponować uprawianie psychologii w inny sposób niż uznawany przez Mistrza. Rzeczywiście, najtrafniejszym wyjściem było znalezienie dla siebie odpowiedniej niszy naukowej i udowodnienie jej znaczenia dla rozwoju nowoczesnej psychologii. Choć ową (metodologiczną) niszę Kreutz odnalazł, to jednak uczynił niewiele, aby przekonać Twardowskiego do jej wartości, a tym samym poprawić wzajemne relacje oraz swój wizerunek w roli godnego następcy. Jednak mimo że przez długie lata współpraca obu uczonych polegała na stosowaniu sztuki uników i przebiegała w chłodnej atmosferze skrywanej niechęci, maskowanej nadmierną uprzejmością oraz w klimacie nierozwiązanego konfliktu, to za ich sprawą wydarzyło się sporo dobrego dla polskiej psychologii. Twardowski wspólnie bowiem z Kreutzem, a potem już Kreutz samodzielnie, zdołali wykształcić kolejne pokolenia psychologów, spośród których do szczególnie uzdolnionych należeli: Walter Auerbach (zm. 1944) - uczeń również Witwickiego, Eugenia Blaustein (1905-1944), Leopold Blaustein (1905-1944), Andrzej Lewicki (1910-1972) czy Tadeusz Tomaszewski (1910-2000).

46 Ibidem. 


\section{Kazimierz Twardowski as a master and principal}

\section{Keywords}

History of Polish science, "master - pupil" relation

On the basis of the Kazimierz Twardowski's diary, its analysis and also excerpts from his letters to Władysław Witwicki, I describe: (1) the essence and causes which made the "Twardowski-Kreutz" relation so complicated; (2) the untold story of an uphill battle for the department of psychology in University of Jan Kazimierz and for Kreutz's scientific degrees. 